$\begin{array}{llllllllllllllll}\mathrm{R} & \mathrm{E} & \mathrm{P} & \mathrm{U} & \mathrm{B} & \mathrm{L} & \mathrm{I} & \mathrm{K} & \mathrm{A} & & \mathrm{S} & \mathrm{I} & \mathrm{O} & \mathrm{S} & \mathrm{T} & \mathrm{R}\end{array}$

\title{
Katarzyna Waligóra
}

Uniwersytet Jagielloński w Krakowie

\section{„JESTEŚMY ZBIERANINĄ, \\ POSPOLITYM RUSZENIEM DOBREGO I ZEEGO" Manuela Gretkowska zakłada Partię Kobiet}

„We Are Madley, a Mass Conscription of a Good and Evil" Manuela Gretkowska Sets Up the Women's Party 


\begin{abstract}
Abstrakt: Artykuł jest próbą przyjrzenia się Partii Kobiet założonej przez pisarkę i publicystkę, Manuelę Gretkowską w 2007 z perspektywy żenującego kobiecego performansu - wystąpienia jednocześnie emancypacyjnego i budzącego konsternację wśród jego odbiorców. Przedstawiono moment powstania partii i przeanalizowano warunki społeczno-polityczne jej zaistnienia oraz trudności, które od początku napotykały działaczki organizacji. Omówiono też reakcje medialne towarzyszące tworzeniu i działalności Partii Kobiet. Autorka stawia tezę, że porażka wyborcza, jaką ostatecznie poniosła inicjatywa Manueli Gretkowskiej, związana była z dążeniem do wygaszenia żenującego performansu i pójściem na daleko idące kompromisy światopoglądowe. Dowodzi, że w przypadku Partii Kobiet ważniejszy niż program polityczny był imperatyw działania, który miał pchnąć kobiety do upolitycznienia swoich potrzeb.
\end{abstract}

Słowa kluczowe: Partia Kobiet, kobiety w polityce, feminizm, polityka, upolitycznienie potrzeb, kobiety i władza, Manuela Gretkowska

\begin{abstract}
This article looks at the Women's Party, founded by the Polish author and columnist Manuela Gretkowska in 2007, from the perspective of 'embarrassing female performance' - an initiative that is empowering yet leaves the audience baffled. The author discusses the founding of the party, analysing the socio-political conditions of its emergence and the difficulties encountered by its activists since its beginning. The article also presents the media's response to the establishment and activity of the party. The author claims that the defeat that Manuela Gretkowska's initiative ultimately suffered in the election was connected with its gradual departure from the embarrassing performance format as well as with the acceptance of far-reaching ideological compromises. She argues that in the case of the Women's Party, the political program was overshadowed by the imperative to act, aimed at pushing women to politicize their needs. (Transl. Z. Ziemann)
\end{abstract}

Keywords: Women's Party, women in politics, feminism, politics, politicization of needs, women and power, Manuela Gretkowska 
$\mathrm{W}$ wyborach parlamentarnych, które odbyły się 21 października 2007, Partia Kobiet zarejestrowana 11 stycznia tego samego roku przez pisarkę i publicystkę Manuelę Gretkowską poniosła spektakularną klęskę, zdobywając zaledwie 0,28 procenta głosów. Oznaczało to, że ugrupowanie nie tylko nie uzyskało żadnych mandatów, ale także nie mogło liczyć na subwencję z budżetu państwa pozwalającą na dalszy rozwój. Założycielka partii zrezygnowała z funkcji przewodniczącej, pozostając przez jakiś czas przewodniczącą honorową. Przez kolejne trzynaście lat Partia Kobiet startowała w różnych wyborach, a jej największym sukcesem okazało się zdobycie jednego mandatu w Radzie Dzielnicy Mokotów w Warszawie w wyborach samorządowych w 2010․ . W 2014 partia zmieniła nazwę na Inicjatywę Feministyczną. 20 stycznia 2020 liderki ugrupowania poinformowały o jego rozwiązaniu.

Założenie Partii Kobiet jest przykładem tego, co określam mianem żenującego kobiecego performansu - jednocześnie emancypującego i budzącego konsternację wśród tych, którzy są jego odbiorcami². Choć pomysłodawczynią i przewodniczącą była pisarka, nie uważam założenia partii za działanie artystyczne (ani, jak sugerowali niektórzy komentatorzy, za część kampanii promocyjnej powieści jej inicjatorki). Słowa performans używam, żeby pokreślić sprawczość gestu Gretkowskiej, jej aktywną postawę oraz żeby położyć nacisk na działanie. Natomiast żenada nie jest w moich badaniach pejoratywnym określeniem, a neutralną i adekwatną nazwą strategii polegającej na przeprowadzaniu swoich zamierzeń, choć są one wyśmiewane, dyskredytowane i budzą negatywne emocje. Opowieść o żenującym performansie założenia Partii Kobiet zaczynam od końca, od porażki wyborczej decydującej o politycznej marginalizacji ruchu, która wraz z upływem lat tylko postępowała. Jednak w pierwszym roku istnienia partia była interesującym bytem wzbudzającym skrajne emocje: od wielkich nadziei, przez rozczarowanie i zniechęcenie, po wściekłość i pogardę. Co ważniejsze, negatywne emocje w przypadku Partii Kobiet rozchodziły się wielokierunkowo - odczuwali je jej

Cytat w tytule: M. Gretkowska, Obywatelka, Warszawa 2008, s. 134.

1 Członkinie partii startowały z list Sojuszu Lewicy Demokratycznej oraz komitetów lokalnych.

2 Więcej na temat tego, czym jest żenujący performans zob. K. Waligóra, Czy pani jest bardzo glupia czy bardzo inteligentna? Joanna Szczepkowska i żenujacy performans odwołania komunizmu, „Didaskalia” nr 145-146 (2018). 
oponenci (tu szczególnie widoczne będzie uczucie zażenowania), ale także potencjalni lub byli sympatycy (tu dominować będzie wściekłość i rozczarowanie). Chciałabym pokazać, że żenujący performans nadawał partii największą żywotność, a jej wyborcza porażka była związana z próbami jego wygaszenia.

1.

Partia Kobiet powstała wskutek momentu załamania ${ }^{3}$ (snap), który zwykle poprzedza żenujący performans. W 2006 władzę w Polsce dzierżyła koalicja trzech prawicowych partii: Prawa i Sprawiedliwości, Ligi Polskich Rodzin oraz Samoobrony. Wśród głośnych propozycji legislacyjnych, procedowanych w parlamencie w tamtym czasie, jedną z najważniejszych była próba wpisania do konstytucji obowiązku ochrony życia ludzkiego „od poczęcia do naturalnej śmierci”. Ten zapis, zaproponowany przez posłów 7 września 2006 i ostatecznie odrzucony przez większość parlamentarną 13 kwietnia 2007, mógłby pociągać za sobą całkowity zakaz aborcji. Dyskusja o prawie do przerywania ciąży na nowo zagościła we wszystkich mediach.

W takich właśnie okolicznościach Gretkowska zdecydowała się powołać Partię Kobiet. W 2008 pisarka wydała dziennik Obywatelka - trzeci w cyklu po Polce (dzienniku ciąży, Warszawa 2001) i Europejce (dzienniku dokumentującym życie prywatne autorki w okresie wstępowania Polski do Unii Europejskiej, Warszawa 2004). Można go czytać jako tekst programowy i szczegółowe sprawozdanie z historii partii od chwili powstania do pierwszej wyborczej porażki. Wybrana przez Gretkowską konwencja gatunkowa daje wgląd w intymne motywacje pisarki, która patrząc w ogień płonący w kominku podwarszawskiego domu (zamieszkiwanego wspólnie z partnerem Piotrem Pietruchą i sześcioletnią córką Polą), uznaje, że czas działać.

Sarah Ahmed o załamaniu (snap) pisała następująco:

Kiedy myślimy o takich momentach załamania nerwowego [moments of snap], o tych momentach kiedy już nie możesz tego wytrzymać, po prostu nie możesz wytrzymać, myślimy o zasadach działania świata. O tym, jak świat jest zorganizowany, żeby dawać powietrze jednym, utrudniając oddychanie innym ${ }^{4}$.

3 Angielskie słowo snap (szerzej objaśnione przez Sarah Ahmed) jest bardzo trudne do oddania w języku polskim i można je tłumaczyć wymiennie jako „załamanie”, ,pęknięcie”, ,zerwanie”. Ahmed używa go do opisania sytuacji, w której jednostka doświadcza wzburzenia emocjonalnego popychającego ją do działania niemożliwego do podjęcia w innych okolicznościach. Właśnie ze względu na ten afektywny wymiar pojęcia w niniejszym tekście tłumaczę je jako „załamanie”. Eadem, Living a Feminist Life, Durham - London 2017.

4 S. Ahmed, Snap! Feminist Moments, Feminist Movements, https://feministkilljoys.com/2017/05/21/ snap/ [dostęp: 10 VII 2019]. Przekłady, jeśli nie zaznaczono inaczej - K. W. 
Ahmed pokazuje związek między załamaniem a momentem rozpoznania: podmiot dostrzega zasady organizujące świat, które sprawiły, że znalazł się w nieznośnym położeniu. Gretkowska nie mogła znieść kolejnej debaty o prawie do przerywania ciąży nieuwzględniającej głosu kobiet. Moment załamania pozwolił jej na rozpoznanie najważniejszego czynnika, który doprowadził do tej sytuacji: głos kobiet nie jest słyszany, bo nie musi być słyszalny - nie musi być słyszalny, bo nie jest głosem politycznym, więc jego lekceważenie nie przynosi skutku w postaci przegranych wyborów. Dlatego zaproponowała następujące rozwiązanie:

Nie musimy się buntować, bunt jest bronią niewolników. My, kilkanaście milionów dorosłych Polek, żyjemy w europejskiej demokracji i jesteśmy pełnoprawnymi obywatelami. Mamy wszelkie możliwości sięgnąć po władzę i przestać się gapić na to, co z nami wyrabiają. [...] Nie wystarczy pójść na manifestację przeciw prawu antyaborcyjnemu. Żeby załatwić wszystkie nasze sprawy, musiałybyśmy chodzić codziennie pod sejm. Skuteczniej będzie do niego wejść na stałe, nie kilkuosobową reprezentacją, ale silną partią 5 .

Deklaracja ta pochodzi z manifestu Dość upokorzeń opublikowanego 16 listopada 2006 na łamach tygodnika „Przekróo”. Tytuł tekstu potwierdza, że afektywnym źródłem przedstawionych w nim postulatów było załamanie, ale też wskazuje, że moment pęknięcia został twórczo zagospodarowany. Głównym tematem manifestu był brak dostępu do aborcji:

Każda kobieta ma prawo decydować o tym, czy ją stać emocjonalnie, materialnie zachować nieplanowaną ciążę. Nie jesteśmy państwem wyznaniowym, więc co może obchodzić niewierzącą Kowalską fanatyzm Wiśniewskiej, według której Duch Święty pracuje w prokuraturze i szpera w wyskrobanych macicach ${ }^{6}$ ?

Gretkowska pisała także o przemocy, jakiej kobiety doświadczają od najmłodszych lat, przywołując sprawę samobójstwa czternastoletniej Ani z Gdańska ${ }^{7}$, o słabej ochronie prawnej i socjalnej kobiet wychowujących dzieci, o złych warunkach porodów, o braku edukacji seksualnej i dominacji Kościoła katolickiego. Pisarka w całym tekście szukała dosadnych i adekwatnych określeń, nazywając po imieniu problemy, z którymi mierzą się kobiety. Jej manifest przenika poczucie siły i natchnienia. Celowo używam w tym miejscu romantycznych kategorii, bo Gretkowska bardzo świadomie odwoływała się do patetycznego ducha męskich odezw do narodu (proponowała, żeby partię organizować metodami wypracowanymi przez

5 M. Gretkowska, Dość upokorzeń, „Przekrój” 2006 nr 46, s. 27.

6 Ibidem, s. 26.

7 Dziewczynka odebrała sobie życie po tym, jak doświadczyła przemocy i molestowania seksualnego ze strony kolegów z klasy. O tej sprawie zob. M. Mazuś, Dziecko wybrało śmierć, winnych brak, „Polityka” 2014 nr 4, https://www.polityka.pl/tygodnikpolityka/spoleczenstwo/1567597,1,dzieckowybralo-smierc-winnych-brak.read [dostęp: 29 VII 2020]. 
Armię Krajową), a jednocześnie odkształcała go za pomocą dosadnych zdań takich jak: „My nie mamy jak one [wyznawczynie islamu] zasłoniętych szmatami oczu, my je mamy dobrowolnie zamknięte" albo: „Nie wiem, z jakim rodzajem kobiet obcują w nawale zajęć posłowie, ale jest to raczej opis gumowej lali, niż kobiety z krwi i kości”". Na łamach feministycznej „Zadry” Beata Kozak oceniła, że ten

feministyczny manifest napisany bez użycia słowa „feminizm”, za to z sugestywnym obrazem Polski jako kobiety i ze skupieniem się na macierzyństwie i postulatach poprawy sytuacji socjalnej kobiet - trafia i porywa ${ }^{10}$.

Publikację manifestu Dość upokorzeń uznaję za moment zainicjowania przez Gretkowską żenującego kobiecego performansu. Bardzo wyraźnie chcę jednak nakreślić granice tego, co w tym przypadku określam tym pojęciem. Performansem jest $\mathrm{w}$ moim przekonaniu akt założenia partii oraz część prowadzonej przez nią działalności. Jak za chwilę chciałabym pokazać, chodzi o tę część, której ambicją było wprowadzenie daleko idących zmian w sferze publicznej, w sposobie dystrybucji uwagi w debacie medialnej, politycznej i społecznej oraz w określaniu tematów i problemów jako politycznych. Żenujące techniki w przypadku tego performansu będą związane z wizerunkiem Manueli Gretkowskiej, z trybem działania Partii Kobiet oraz ze sposobami autopromocji. Wszystkie inne elementy działalności partyjnej, szczególnie zarys programu, z którym ostatecznie organizacja startowała w wyborach, oraz aspekty ideowe większości wypowiedzi jej liderki znajdują się poza granicami performansu. Chciałabym udowodnić, że w przypadku inicjatywy Manueli Gretkowskiej żenujący performans był siłą napędową, oferował możliwość realnego przekształcenia sposobu uprawiania polityki, jednak został wygaszony, kiedy liderka Partii Kobiet uznała, że miejsca w parlamencie można zdobyć innymi metodami. Zmiana okazała się zresztą dość radykalna, bo wygaszając wywrotowe techniki żenującego performansu, Gretkowska postanowiła wejść na pole konserwatyzmu.

2.

W tekście Walka o potrzeby. Zarys socjalistyczno-feministycznej krytyki kultury politycznej późnego kapitalizmu Nancy Fraser przedstawia model obrazujący, w jaki sposób wytwarzana jest możliwość interweniowania w swoich sprawach przez różne grupy interesu ${ }^{11}$. Zdaniem badaczki każda potrzeba

8 M. Gretkowska, Dość upokorzeń, op. cit., s. 26.

9 Ibidem, s. 27.

${ }^{10}$ B. Kozak, Kobiecizm, „Zadra” 2006 nr 4, s. 33.

${ }^{11}$ N. Fraser, Walka o potrzeby. Zarys socjalistyczno-feministycznej krytyki kultury politycznej późnego kapitalizmu, [w:] eadem, Drogi feminizmu. Od kapitalizmu państwowego do neoliberalnego kryzysu, przeł. A. Weseli, Warszawa 2014. 
wyrażana przez określoną grupę ludzi, jeśli ma zostać zaspokojona środkami państwowymi, musi najpierw uzyskać status polityczny. Trzeba ją przenieść ze sfery prywatnej w obszar polityczny. Jeśli więc chcemy zwalczać przemoc domową, musimy najpierw wykazać, że nie jest ona sprawą prywatną, problemem konkretnych par, nie tworzy odizolowanych od siebie przypadków, lecz jest problemem systemowym, którym powinno zająć się państwo. Kiedy potrzeba zyska już status polityczny, rozpoczyna się walka o prawo do jej interpretacji oraz do proponowania środków jej zaspokojenia. W grę wchodzą różne interesy: w przypadku przemocy domowej inną interpretację zastosuje konserwatywny, katolicki polityk, który za wszelką cenę będzie dążył do utrzymania jedności rodziny, a inną feministka, która będzie chciała skupić się na odizolowaniu ofiary od sprawcy. Trzecim stopniem jest walka o faktyczne zaspokojenie potrzeby jeśli bowiem nawet wszyscy zgodziliby się, że państwo powinno interweniować w sprawie przemocy domowej i doszłoby do uchwalenia prawa pozwalającego chronić ofiary, niekoniecznie prawo to zostanie wcielone w życie. Ponieważ głosy mówiące o potrzebach i przedstawiające ich interpretacje są zróżnicowane - jedne należą do grup sprawujących władzę, inne do grup poddanych opresji lub wykluczonych - Fraser podkreśla ich heterogeniczny i antagonistyczny charakter. Język potrzeb jest zatem polem walki: grupy (o nierównych zasobach) rywalizują o to, żeby ustanowić swoje interpretacje potrzeb społecznych jako hegemoniczne. Grupy wykluczone chcą zmienić lub zmodyfikować oficjalne interpretacje, podczas gdy grupy dominujące walczą o ich utrzymanie - interpretacja jest więc aktem i interwencją, a nie reprezentacją.

Z modelu Fraser możemy wyprowadzić dwie obserwacje. Po pierwsze, upolitycznione potrzeby stają się przedmiotem politycznej gry: mogą przekształcić się w obietnicę wyborczą, kartę przetargową w działaniach partyjnych, a ich realizacja może wpłynąć na poziom satysfakcji wyborczej. W ten sposób wchodzą w obieg, dzięki któremu mogą zostać zaspokojone. Po drugie, samo zdefiniowanie potrzeby jako politycznej jest niewystarczające - jeśli bowiem ma czemuś służyć, musi pociągać za sobą wytworzenie siły politycznego nacisku, która zadba o jej zaspokojenie. Oczywiście w ramach teorii Fraser tworzenie owej siły nacisku nie musi sprowadzać się do zakładania partii politycznych. Zauważmy jednak, że Gretkowska w momencie załamania zwróciła uwagę na problem dostępu do aborcji. Po zmianie prawa o dopuszczalności przerywania ciąży w 1993 pozapartyjnym ruchom kobiecym kilkukrotnie udało się wytworzyć siłę politycznego nacisku zdolną zablokować plany zaostrzenia ustawy (najbardziej spektakularnym tego przykładem były tak zwane Czarne Protesty w 2016), nie zdołały jednak doprowadzić do jej liberalizacji. Zdobycie miejsc w parlamencie mogłoby więc w tym przypadku dawać szansę na realną zmianę. 
Jak jednak thumaczy Mary Beard „Kobiety u władzy postrzega się jako przełamujące bariery lub ewentualnie sięgające po coś, do czego nie są w pełni uprawnione" 12 . Beard pokazuje, że wyobrażenia o sprzeczności między kobiecością a władzą (szczególnie polityczną) towarzyszą kulturze od czasów antycznych. To prowadzi ją do konkluzji, że: „Fundamentalny rozdział - realny, kulturowy i symboliczny - między kobietami a władzą pojawił się tak dawno, że z tego, co wiemy, nie było w historii Zachodu epoki, w której by nie występował"13. Badaczka zauważa również, że dopuszczenie pewnej liczby kobiet do władzy (zwykle są to kobiety, od których wymaga się spełniania określonych kryteriów, na przykład wizerunkowych) w gruncie rzeczy umacnia model, w którym kobiety jako grupa są wykluczone ze sprawowania władzy. Beard pisze:

Wciąż jednak oznacza to traktowanie władzy jako czegoś elitarnego, powiązanego z prestiżem, charyzmą jednostki nazywanej przywódcą i często, choć nie zawsze, ze statusem celebryty. A także traktowanie władzy bardzo wąsko jako czegoś, co tylko nieliczni - głównie mężczyźni - mogą posiadać lub dzierżyć [...]. Przy takich założeniach kobiety jako płeć - a nie konkretne osoby - są z niej z definicji wyłączone. Nie da się łatwo wpasować kobiet w strukturę od początku zaprogramowaną jako męską - trzeba tę strukturę zmienić. Oznacza to zmianę w myśleniu o władzy. Oznacza oddzielenie jej od prestiżu' ${ }^{14}$.

Jedna z najbardziej znanych teoretyczek performansu, Erika Fischer-Lichte pokazuje następujący wariant przedstawienia: performer lub performerka (autorka posługuje się przykładem Rythm 0 Mariny Abramović) buduje pewną otwartą sytuację, a widzowie mają różne możliwości jej wykorzystania. Fischer-Lichte podkreśla ambiwalencję performatywności wywołaną stanem niedookreślenia w przypadku Abramović

nie-działanie artystki wyłoniło sytuację, która nie była ani jednoznacznie społeczna, ani jednoznacznie estetyczna [...]. Tym samym zebrani w galerii znaleźli się w sytuacji intensywnie doświadczanej liminalności ${ }^{15}$.

Performans ma zatem działanie destabilizujące. W innym miejscu Fischer-Lichte dodaje, że dwie nierozerwalnie ze sobą związane i występujące symultanicznie siły performatywności to destrukcja i kreacja ${ }^{16}$. Pisząc o performansie, niemiecka badaczka ma na myśli albo wydarzenia artystyczne, albo przedstawienia kulturowe, ale jej obserwacja może być pomocna w rozumieniu działań Manueli Gretkowskiej. Wydaje się bowiem, że przynajmniej na początku politycznej kariery

12 M. Beard, Kobiety i władza. Manifest, przeł. E. Hornowska, Kraków 2018, lok. mobi 387.

3 Ibidem, lok. 467.

4 Ibidem, lok. 572.

15 E. Fischer-Lichte, Performatywność, przeł. M. Sugiera, M. Borowski, Kraków 2018, s. 122.

16 Por. ibidem, s. 127. 
działania liderki Partii Kobiet powodowały rozstrojenie tego, co Beard nazwała męską strukturą sprawowania władzy. Skoro zaś struktura ta powiązana jest z powagą i prestiżem, Gretkowska sięgnęła po techniki żenującego kobiecego performansu, bo jego subwersywny potencjał dobrze nadaje się do destabilizowania tych dwóch obszarów.

\section{3.}

Założenie partii politycznej jest zawsze performansem kulturowym: ustanawia nowy byt, którego celem jest przekształcanie sfery publicznej, a przy tym podporządkowany jest pewnej strukturze i posługuje się zestawem technik widowiskowych (takich jak organizowanie dużego wiecu inauguracyjnego, wygłaszanie przemówień i haseł, prezentacja postulatów i programu, udzielanie wywiadów). Zakładając Partię Kobiet, Manuela Gretkowska w pewnym stopniu wpisywała się oczywiście w ogólny schemat tego tradycyjnego performansu, ale jednocześnie przekraczała go, tworząc żenujący kobiecy performans. Właśnie dlatego jej inicjatywa miała szansę przekształcić opisaną powyżej strukturę władzy.

Na pytanie, dlaczego feministki nigdy wcześniej nie założyły partii, Gretkowska odpowiedziała w jednym z wywiadów: „bo nie były walniętymi artystkami”"17. Ta odpowiedź jest znacząca, bo Gretkowska przechwytuje w niej i eksponuje epitet, którym wielu zupełnie serio chciało ją obdarzyć. W momencie założenia partii była jedną z najbardziej znanych polskich pisarek (jedną z nielicznych utrzymujących się z pisania), autorką bestsellerów, przede wszystkim jednak artystką-skandalistką. Opublikowała powieść, której bohaterka miała dwie waginy ( $\mathrm{Ka}$ baret metafizyczny, Warszawa 2012), fabularyzowaną historię swojego romansu z Andrzejem Żuławskim (Trans, Warszawa 2011), opowiadanie erotyczne (Sceny z życia pozamałżeńskiego, Warszawa 2003) czy intymny dziennik ciąży (Polka). Stale publikowała też felietony, w których komentowała bieżące życie polityczne - właściciel miesięcznika „Sukces” jeden z nich wyciął ręcznie nożyczkami z już wydrukowanego, a jeszcze nieoddanego do dystrybucji numeru, żeby nie narazić się braciom Lechowi i Jarosławowi Kaczyńskim (wówczas pełniącym funkcję prezydenta i premiera RP) ${ }^{18}$. Gretkowska znana była też z tego, że umiała walczyć o wysokie honoraria, co wielu przyjmowało z niesmakiem. Przede wszystkim jednak nie bała się pisać i mówić o kobiecych doświadczeniach uznawanych za

17 Mordobicie z lilijka w klapie. Z Manuela Gretkowska rozmawiała Eliza Olczyk, „Rzeczpospolita" [online 9 II 2019], https://archiwum.rp.pl/artykul/1396247-Mordobicie-z-lilijka--w-klapie.html [dostęp: 29 VIII 2020].

18 Felieton Gretkowskiej można dziś, podobnie jak w 2006, z łatwością znaleźć w internecie: https://www.empik.com/empikultura/przeczytaj-wyciety-felieton-dyskretny-gust-kancelariiprezydenta,4505,a [dostęp: 30 VII 2020]. 
żenujące: orgazmach, miesiączkach, ciąży, menopauzie. Kiedy debiutowała, za wzór stawiano jej Olgę Tokarczuk, żądając uładzenia wybujałej wyobraźni. Jak wspomina Gretkowska: „Pisano «oryginalna», ale były też opnie, że grafomanka, idiotka. Oburzenie panowało wielkie, wystawiano recenzje moich nóg"19. Jednym ze znaków rozpoznawczych pisarki, co widać wyraźnie również w manifeście Dość upokorzeń, była umiejętność bezczelnie dosadnego formułowania opinii i wspierania ich obrazowymi metaforami. Na przykład wspominając pejoratywny termin „literatura menstruacyjna”"20, którym określano jej powieści, Gretkowska stwierdziła: „Z wrażenia na cześć Błońskiego przestałam miesiączkować”21.

Kiedy zdecydowała się założyć partię, jej wcześniejsze działania, sposób, w jaki wyrażała opinie, fragmenty jej prozy zaczęły rezonować w wyobraźni odbiorców. Działalność Gretkowskiej potęgowała lęk przed nią i jej pomysłami. „Partia Kobiet nie chce seksmisji!”22, „,seksmisja na żywo?”23, „żadnej seksmisji nawet na Śląsku nie będzie?”24, „seksmisję sobie urządzają"25 - krzyczały prasa i fora internetowe. Seksmisja - film wyreżyserowany przez Juliusza Machulskiego, który trafił do kin w 1987, pokazywał wizję państwa zarządzanego wyłącznie przez kobiety. Przedstawione w nim bohaterki są mściwe, głupie, słabe, niezaspokojone seksualnie, ale przede wszystkim nieudolne. Dystopia, którą tworzą, nie jest przerażająca - jest śmieszna. W momencie powstania film Machulskiego skanalizował lęki przed feminizmem, którego nadejście w latach osiemdziesiątych bardziej przeczuwano niż doświadczano. Stał się też tekstem kultury, który zgodnie z tezami Beard umacnia wyobrażenia o nieprzystawalności kobiet do władzy. Jego oddziaływanie na tym polu jest niezwykle silne, bo pochodzące z niego obrazy, cytaty (najbardziej chyba znany to: „Samiec twój wróg!”), metafory nieustannie powracają w polskim dyskursie. Przywoływanie Seksmisji w odpowiedzi na powstanie Partii Kobiet było oczywiście uruchomieniem podręcznego arse-

19 Trudno z miłości się podnieść. Manuela Gretkowska w rozmowie z Patrycją Pustkowiak, Warszawa 2019, s. 97.

20 Autorstwo tego terminu przypisuje się zazwyczaj J. Błońskiemu, a jego rozpowszechnienie K. Vardze. Określano nim twórczość nie tylko Gretkowskiej, ale także I. Filipiak, O. Tokarczuk, Z. Rudzkiej czy H. Kowalewskiej. Zob. A. de Carlo, Ecce femina-podróż do źródeł kobiecości. Wokól krwi menstruacyjnej we współczesnej literaturze polskiej na podstawie wybranych przykładów-Izabeli Filipiak i Olgi Tokarczuk, ,Postscriptum Polonistyczne” 2017 nr 2.

21 Trudno z mitości się podnieść..., op. cit., s. 97.

22 I. Adamczewska, Partia kobiet nie chce seksmisji, „Gazeta Wyborcza Łódź” [online 11 I 2007], https:/classic.wyborcza.pl/archiwumGW/4799297/Partia-Kobiet-nie-chce-seksmisji [dostęp: 11 VIII 2020 ].

23 A. Pszczółkowska, Kobiety niegotowe do wyborów, „Gazeta Wyborcza Białystok” [online 1 IV 2007], https://classic.wyborcza.pl/archiwumGW/4849353/Kobiety-niegotowe-do-wyborow [dostęp: 11 VIII 2020].

24 Kobieta upadta. Z Manuelą Gretkowska rozmawiat Rafat Kreger, „Puls Biznesu” 2007 nr 91 , https://www.pb.pl/kobieta-upadla-369727 [dostęp: 11 VIII 2020].

25 B. Hrybacz, Polska jest kobieta, ,Elle” 2007 nr 4, s. 68. 
nału komicznych wyobrażeń na temat kobiet dążących do władzy. Wydaje się jednak, że te komentarze mają też inne podłoże: zdradzają lęk przed samą Manuelą Gretkowską i tym, co może się stać, jeśli stworzona przez nią organizacja szturmem zdobędzie Sejm. Gretkowska była przecież autorką scenariusza do Szamanki (1996) Andrzeja Żuławskiego, a więc pomysłodawczynią finałowej sceny, w której główna bohaterka wyjada łyżeczką mózg swojego kochanka. Główna bohaterka, uosobienie dzikiej kobiecej seksualności, budziła fascynację, ale przede wszystkim grozę. Czy ta, która stworzyła taką postać, mogła budzić zaufanie?

Beard wskazywała, że czynnikiem stabilizującym obecny patriarchalny system polityczny jest powiązanie władzy z prestiżem. Jeśli przyjmiemy, że system polityczny wymaga powagi i prestiżu, wejście w jego ramy „walniętej artystki” musi generować zażenowanie. Jest jednak być może jedynym sposobem na jego rozstrojenie. Erika Fischer-Lichte pokazywała, że Rythm 0 Mariny Abramović wytwarza pole niepewności, bo nie wiadomo, czy oceniać należy go według kryteriów etycznych, czy estetycznych. Performans Gretkowskiej wytwarzał analogiczne pole niepewności między tym, co estetyczne, a tym, co polityczne. Partia powstała niespodziewanie, założyła ją artystka, publikując w gazecie emocjonalny felieton, a nie poważną odezwę. Powstała, chociaż jej pomysłodawczyni nie posiadała odpowiednich zasobów finansowych, infrastrukturalnych, osobowych i prawnych. Po jej apelu zaczęli zgłaszać się ludzie zainteresowani wykonywaniem różnych prac albo tworzeniem struktur regionalnych, ale nie zawsze kierowali się dobrymi intencjami - jak ujęła to pisarka: ,jesteśmy zbieraniną, pospolitym ruszeniem dobrego i złego" 26 . W Obywatelce Gretkowska portretuje galerię typów odwiedzających tymczasową siedzibę organizacji, na przykład: kobietę wyraźnie cierpiącą na zaburzenia psychiczne, która przyszła wyposażona w duży nóż; inną, której zależało tylko na przekazaniu listu do ministra Zbigniewa Ziobry; specjalistę od PR-u z wyrokiem sądowym za oszustwa, który oferował swoje usługi w zamian za wysokie honorarium; lekarza, któremu powierzono zorganizowanie spotkania eksperckiego z medykami w celu rozmowy o planach partii na naprawę służby zdrowia i który ostatecznie nikogo nie zaprosił, bo nikt jego zdaniem nie był godny wysłuchania. Do Partii Kobiet zgłaszały się także osoby, które chciały zbudować swoją indywidualną polityczną karierę, różnego typu oszuści oraz ci, którzy mylili partię z organizacją społeczną i liczyli na pomoc charytatywną lub prawną.

Pomyłki zdarzały się nawet przy powierzaniu najbardziej odpowiedzialnych stanowisk. Wśród czworga założycieli organizacji (byli to: Manuela Gretkowska, Lidia Popiel, Wiktor Osiatyński i Ilona Kanclerz) bardzo szybko wybuchł konflikt,

26 M. Gretkowska, Obywatelka, op. cit., s. 134. 
który niemal doprowadził Gretkowską do utraty władzy ${ }^{27}$. Pisarka opowiadała o nim zawsze z plotkarską szczerością: u jego podłoża widziała romans i miłosne szaleństwo, a nie wyrafinowane rozgrywki, których moglibyśmy spodziewać się w tradycyjnym partyjnym performansie. Przy okazji tego sporu wyszło na jaw, że autor statutu partii z wykształcenia był chemikiem, a nie prawnikiem, za którego uchodził wśród członkiń i członków organizacji. Nic dziwnego, że obserwujący działania Partii Kobiet czuli się zdezorientowani - mówili na przykład, że „trudno też stwierdzić, czy Gretkowska chce być politykiem, czy też może matką albo pisarką. Publicznie mówiła, że celem jej życia jest wychowanie sześcioletniej córeczki Poli”28. Nikt nie mógł mieć pewności, czy Partia Kobiet nie jest żartem albo prowokacją. Innymi słowy, nikt nie miał pewności, czy traktując ją poważnie, ostatecznie nie wyjdzie na głupca. Gretkowska tymczasem wykorzystywała konsternację komentatorów, atakując ich za brak powagi, bo jej zdaniem stosunek do Partii Kobiet odzwierciedlał stosunek do wszystkich Polek.

To właśnie przeniesienie wizerunku i strategii estetycznych wypracowanych na gruncie artystycznym w obszar polityczny pozwoliło na przekształcenie tradycyjnego performansu powstania partii w żenujący kobiecy performans. $\mathrm{Na}$ przykład Gretkowska nie zamierzała być ani liderką naśladującą mężczyzn, ani polityczką wpisującą się w kanon wizerunkowy wyznaczany przez męski system władzy. Na pierwszym plakacie Partii Kobiet stoi obok znanych postaci życia publicznego, aktorek i dziennikarek. Ma na sobie letnią sukienkę w kwiaty i ciężkie, zimowe buty. W Obywatelce pisze, że w czasie sesji nie miała z kim zamienić się obuwiem, zresztą była tak zmęczona, że wszystko było jej obojętne ${ }^{29}$. W wystąpieniach telewizyjnych też większą wagę przywiązywała do tego, co chce powiedzieć, niż do tego, jak wygląda. Nie nosiła ani garsonek, ani mocnego makijażu, jej znakiem rozpoznawczym od lat była burza srebrnych włosów, choć Polki zwykle maskują siwiznę. Na jeden z wywiadów do studia telewizji TVN Gretkowska przyszła z sześcioletnią córką Polą ${ }^{30}$. W czasie nagrania dziewczynka swobodnie krążyła po pomieszczeniu, bawiła się, biegając na czworaka, tańczyła tuż przed kamerą, chowała się za fotelami i stroiła śmieszne miny. Prowadzący wywiad Jarosław Kuźniar starał się skupić uwagę na pisarce, ale kiedy nieco poirytowanym głosem poprosił Polę o powrót na miejsce, Gretkowska upomniała go, żeby nie ograniczał wolności dziewczynki. Zabranie córki do telewizyjnego studia było

27 Por:: ibidem; Trudno z mitości się podnieść, op. cit.

28 E. Olczyk, Manuela Gretkowska - polityk bez pogladów, „Rzeczpospolita” [online 29 IX 2007], https://archiwum.rp.pl/artykul/720996-Manuela-Gretkowska---polityk-bez-pogladow.html [dostęp: 29 VII 2020].

29 Por. M. Gretkowska, Obywatelka, op. cit., s. 62.

30 Por. Kobiety sa przyszłościa, TVN24, 19 IV 2008, https://tvn24.pl/polska/kobiety-sa-przyszloscia-ra55713-3705929 [dostęp: 2 VIII 2020]. 
w gruncie rzeczy bardzo zgrabnym manifestem. Pisarka pokazała w ten sposób, że praktykowanie polityki nie musi wiązać się z zaniedbaniem macierzyństwa. Podkreśliła prawo matek i dzieci do swobodnego zajmowania przestrzeni publicznej (zwłaszcza że pozwoliła Poli zachowywać się w sposób naturalny dla sześciolatki - nie żądała od niej wcielenia się w rolę „grzecznego dziecka”). A próbując jednocześnie nadzorować zachowanie córki i nie stracić wątku w rozmowie, pokazała, w jakich warunkach pracuje część kobiet. Wiele matek decyduje się przecież wykonywać pracę zarobkową w domu, by nie ponosić kosztów zatrudniania opiekunek. Ale przyjście do telewizji z córką było także gestem żenującym, bo Gretkowska naruszyła wizerunek profesjonalnej polityczki, która potrafi sprawnie manewrować między życiem prywatnym a zawodowym.

Pisząc o sobie, liderka Partii Kobiet tworzyła natomiast obraz raczej natchnionej wieszczki niż poważnej liderki:

Jestem tak pewna słuszności argumentów, prostoty rozwiązań, że scena staje się pasem startowym dla pomysłów, idei, dla mnie. Deski wydłużają się, światła zlewają w świetlisty drogowskaz. Unoszę się ponad thum, jeszcze widzę pojedyncze twarze. Oczy, skupione na moich słowach, prowadzą mnie, dają mrugnięciem znaki, czy zmierzam w dobrym kierunku. Ale ja już siebie nie słyszę, nie mam pojęcia, co zaraz powiem. Wpadłam w trans, boję się utraty przytomności ${ }^{31}$.

Gretkowska bez oporów korzystała ze statusu popularnej pisarki, żeby promować Partię Kobiet. O organizacji mówiła na przykład w czasie spotkań z czytelnikami swojej nowej powieści Kobieta i mężczyźni (Warszawa 2007) ${ }^{32}$. Szczególnie dobrze umiała wykorzystać zainteresowanie, którym zawsze darzyła ją prasa kobieca - udzieliła dużego wywiadu „Gali”"33, o sytuacji kobiet wspomniała w rozmowie dla „Zwierciadła”34, dziennikarce „Elle” ułatwiła napisanie reportażu o partii ${ }^{35}$. Zdawała sobie sprawę, że kolorowa prasa to doskonałe forum - jest przecież tworzona z myślą o jej potencjalnych wyborczyniach, kobietach, które chciała zmobilizować i których głosy były z jej perspektywy ważniejsze niż głosy męskiego elektoratu. Jednocześnie potencjał tego typu pism pozostaje zwykle niedoceniony, bo uznawane są za niepoważne i mało prestiżowe.

Tworząc od podstaw partyjne struktury, Manuela Gretkowska wspólnie z najbliższymi współpracownikami podróżowała po Polsce i organizowała spotkania z kobietami zainteresowanymi działalnością polityczną. Te działania, opisane

31 M. Gretkowska, Obywatelka, op. cit., s. 65.

32 Eadem, Traktuję mężczyzn tagodnie, „Gazeta Wyborcza Lublin” [online 14 III 2007].

33 Na partyjne zebrania jeżdżę z moją Pola. Z Manuela Gretkowska rozmawiała Sylwia Borowska, „Gala” 2007 nr 9.

34 Eadem, 7 smaków, wysłuchała H. Halek, „Zwierciadło” 2007 nr 8.

35 B. Hrybacz, op. cit. 
w Obywatelce, były przedmiotem zainteresowania lokalnych wydań „Gazety Wyborczej”. Teksty na ich temat - co znaczące - pisały wyłącznie kobiety. W Bydgoszczy Emilia Iwanciw przeprowadziła rozmowę z Katarzyną Woźniak, koordynatorką regionalnego oddziału partii. Zapytała ją między innymi o to, czy partner nie ma nic przeciwko jej działalności politycznej oraz jak spędziła Dzień Kobiet ${ }^{36}$. Spotkania partyjne opisywano jako babskie pogaduchy, a nie merytoryczne dyskusje:

Na początku było drętwo. Panie się nie znały, były nieufne. Za nic nie chciały być sfotografowane. Lody zostały przełamane, gdy zaczęły przedstawiać swoje oczekiwania wobec tworzącej się Partii Kobiet ${ }^{37}$.

Wizerunek żenującej, babskiej partii, był przez działaczki przechwytywany lub wręcz prowokowany. Chcąc zaangażować kobiety dotąd stroniące od polityki, stosowały różne strategie zapraszania ich na partyjne spotkania:

Członkinie i sympatyczki Partii Kobiet spotkały się w Piwnicy Związku Polskich Artystów Plastyków. Do udziału w „Babskim Tyglu” zaprosiły swoje córki i koleżanki. Przy świecach, winie i piwie rozmawiały nie tylko o polityce. Chwaliły się literackimi i plastycznymi talentami. W restauracji przy ul. Piotrkowskiej 86 można było podziwiać zdjęcia, obraz, projekty ogrodów, a także wiersze, które tworzą członkinie Partii Kobietº ${ }^{38}$.

Gretkowska również miała świadomość, że w celu aktywizacji wyborczyń trzeba sięgnąć po techniki odmienne od tych, które dotąd stosowały inne partie:

A gdyby zaproponować współpracę, którejś z firm produkujących podpaski? - myślę głośno. - [...] Zamiast nalepki z powtarzalnym logo firmy, dane statystyczne o sytuacji Polek? Nasze postulaty.

Wiem, „niesmacznie głupie”. Ale dlaczego by nie? Siedząc w łazience parę minut, można coś przeczytać, nie tylko skład kosmetyków. Jesteśmy siostrami krwi, a nie transfuzji perfum ${ }^{39}$.

Gretkowska nie miała też oporów przed sięganiem po żenująco kobiece porównania. „Jeżeli kobiety potrafią chodzić po domach z kosmetykami i zakładać kółka obwoźnej sprzedaży szminek, to dlaczego nie mogłyby się zorganizować we własnej obronie?”, pisała w Obywatelce ${ }^{40}$. A na spotkaniach partii mówiła: „Jeśli potrafimy założyć sukienkę, potrafimy też założyć prawdziwą partię polityczną"41.

36 K. Woźniak, E. Iwanciw, Polska jest kobietą, „Gazeta Wyborcza Bydgoszcz” [online 8 III 2007].

37 I. Adamczewska, Łódź też jest kobieta, „Gazeta Wyborcza Łódź” [online 19 XII 2006], https://classic.wyborcza.pl/archiwumGW/4786293/Lodz-tez-jest-kobieta [dostęp: 11 VIII 2020].

38 Ten wieczór należał do pań, „Gazeta Wyborcza Łódź” [online 29 I 2008], https://classic.wyborcza.pl/archiwumGW/5032230/Ten-wieczor-nalezal-do-pan [dostęp: 11 VIII 2020].

39 M. Gretkowska, Obywatelka, op. cit., s. 83.

40 Ibidem.

41 J. Paradowska, Hej, suknie w dłoń, „Polityka” [online 13 X 2009], https://www.polityka.pl/ tygodnikpolityka/spoleczenstwo/200768,1,hej-suknie-wdlon.read?page=98\&moduleId=4686 [dostęp: 10 VIII 2020]. 
To ostatnie zdanie stało się przedmiotem prześmiewczego tekstu Hej, suknie w dłoń opublikowanego na łamach „Polityki”. Strategię tę trafnie podsumował Osiatyński: „Partia żartem? [...] Tym lepiej. Nikt nie będzie nam przeszkadzał”42.

4.

Bardzo trudno obiektywnie zmierzyć rzeczywistą siłę oddziaływania żenującego kobiecego performansu na istniejący system polityczny. Wiemy, że organizacja, której nie dawano szans, którą wyśmiewano i krytykowano, w pierwszym roku działalności rozrastała się o kolejne regionalne oddziały. Wiemy też, że angażowały się w nią kobiety, które dotąd nie uczestniczyły w życiu politycznym. Pewne pojęcie o skuteczności działań Gretkowskiej może też dać uważna lektura niektórych tekstów krytycznych.

W tygodniku „Wprost” o Partii Kobiet ukazało się aż pięć prześmiewczych artykułów - to dużo uwagi, jak na organizację, którą dziennikarze i felietoniści pisma uznali za mało znaczącą. Dodatkowo, w październiku 2007 gazeta przygotowała „ranking najbardziej wpływowych Polek”. Na okładce numeru umieszczono fotomontaż, na którym twarze działaczek z plakatu Partii Kobiet zastąpiono twarzami kobiet, które pojawiły się w rankingu. Hasło „Partia Kobiet. Polska jest kobietą" widniejące na banerze zmieniono na napis „Prawdziwa partia kobiet”. $\mathrm{Na}$ pierwszych trzech miejscach rankingu uplasowały się kolejno: Elżbieta Jaworowicz, Monika Olejnik i Jolanta Kwaśniewska, na dalszych miejscach pojawiły się polityczki: Zyta Gilowska i Hanna Gronkiewicz-Waltz. Miejsce szóste i siódme zajęły Janina Ochojska i Hanna Suchocka, ale nie zobaczymy ich na okładce „Wprost” - zamiast nich pojawiły się Julia Pitera (na fotomontażu to ona zajęła miejsce Gretkowskiej) oraz Nelly Rokita (w 2007 już doradczyni prezydenta Lecha Kaczyńskiego, ale jeszcze nie posłanka). Agata Jakubowska uważa, że decyzja o nieumieszczaniu na okładce Ochojskiej i Suchockiej wynikała stąd, że pierwsza porusza się o kulach, a druga w momencie publikacji numeru pełniła funkcję ambasadorki Polski w Watykanie ${ }^{43}$.

Czyżby próba przeciwstawienia Partii Kobiet nieistniejącej „prawdziwej partii kobiet" wynikała z lęku przed organizacją założoną przez Gretkowską? Na łamach „Wprost” Anita Blinkiewicz i Katarzyna Nowicka pisały:

Wszystko wskazuje jednak na to, że akurat Partia Kobiet okaże się politycznym folklorem. Jej członkinie nastawiły się raczej na wywołanie medialnego zamieszania, a świadczą o tym chociażby wypowiedzi przewodniczącej w stylu: „Lepiej, że łączy nas wspólnota waginy niż wspólnota kolesiostwa". - Kobiety mają polityczną moc sprawczą. Ale zdecydowanie większe

42 M. Gretkowska, Obywatelka, op. cit., s. 94.

43 Zob. A. Jakubowska, Plakat, którego nie widziałam na ulicy, „Czas Kultury” 2008 nr 1, s. 71. 
szanse mają te, które udowodniły wcześniej, że nie pełnią funkcji jedynie dekoracyjnej - mówi socjolog prof. Edmund Wnuk-Lipiński. I to właśnie one stanowią prawdziwą polską partię kobiet. O tym, że Polacy zaczęli doceniać panie, świadczy też przygotowany przez „Wprost” przy współpracy Pentora ranking najbardziej wpływowych kobiet. Wynika z niego, że na kobiety nie tylko chętnie głosujemy, ale też liczymy się z ich opiniami. Aż dwa czołowe miejsca zajęły bowiem dziennikarki zajmujące się tematyką polityczną i społeczną: Elżbieta Jaworowicz i Monika Olejnik ${ }^{44}$.

Zwróćmy uwagę, że to, co w artykule zostało wskazane jako drażniące, to bezczelnie dosadny język Gretkowskiej, niepasujący do wypowiedzi ówczesnych polityków.

Strategia przyjęta przez „Wprost” jest zastanawiająca. W miejsce zorganizowanego ruchu partyjnego tygodnik podsunął grupę niewątpliwie wpływowych, ale niepowiązanych ze sobą kobiet. Znaczące też, że z dwóch wariantów plakatu Partii Kobiet do fotomontażu zdecydowano się użyć tego bardziej kontrowersyjnego, przedstawiającego nagie działaczki. Do samego plakatu wrócę za chwilę, teraz jednak warto zasygnalizować, że „Wprost” oryginalną kampanię partii wyśmiało, więc użycie jej do promocji rankingu wpływowych kobiet było co najmniej dwuznaczne. Co więcej, fotomontaż obejmował tylko zmianę twarzy. Oznacza to, że na okładce pisma „wpływowe kobiety” zawłaszczyły obnażone ciała członkiń Partii Kobiet - zastąpienie ich przez „prawdziwą partię kobiet” nabrało zatem bardzo materialnego wymiaru.

Słowo „wpływowe”, które nie jest tożsame z „posiadające władzę”, stanowi zresztą klucz do odsłonięcia intencji pisma. W miejsce grupy, która domagała się udziału we władzy parlamentarnej, podsunięto wizerunki osób, które zadowalają się wysoką pozycją społeczną i możliwością kształtowania opinii publicznej. A także, co pozostaje niedopowiedziane, zaledwie wpływem na mężczyzn, którzy władzę sprawują. Pismo podsuwa też ranking, w którym kobiety rywalizują ze sobą zamiast rywalizować z mężczyznami o władzę. Okładka tygodnika „Wprost” jest egzemplifikacją tez Mary Beard - pojedyncze kobiety zwykle są niegroźne dla systemu politycznego. Partia Kobiet żądała natomiast nowego podziału władzy, w którym kobiety zyskają realną siłę politycznego nacisku i możliwość realizacji swoich potrzeb. Być może właśnie dlatego o Partii Kobiet przychylnie wypowiedziały się posłanki z zupełnie różnych politycznych opcji: Izabela Jaruga-Nowacka z Sojuszu Lewicy Demokratycznej ${ }^{45}$ i Danuta Hojarska z Samoobrony ${ }^{46}$.

44 A. Blinkiewicz, K. Nowicka, Prawdziwa partia kobiet, ,Wprost” 2007 nr 39, https://www. wprost.pl/tygodnik/114394/Prawdziwa-partia-kobiet.html [dostęp: 2 VIII 2020].

45 Por. E. Olczyk, op. cit.

46 Por. L. Łuniewska, Partia jest blondynka, ,Newsweek” 2007 nr 39. 
5.

Plakat, który stał się podstawą fotomontażu tygodnika „Wprost”, był najważniejszym przykładem działania, w którym Gretkowska zagrała zarówno żenującymi, kobiecymi wyobrażeniami, jak i wyobrażeniami, które mieli na jej temat obserwatorzy performansu. Plakat niewątpliwie był tym, czego po skandalistce i pornografce się spodziewano, nawet jeśli w rzeczywistości można uznać go za dość pruderyjny. Przedstawiał liderkę partii w towarzystwie sześciu innych działaczek - wszystkie kobiety pozowały nago, ale ich intymne części ciała pozostawały zasłonięte. Pięć członkiń partii stało za białym banerem z napisem „Partia Kobiet. Polska jest kobietą”, dwie siedziały z przodu, zasłaniając się skrzyżowanymi nogami i włosami. Hasło na plakacie brzmiało: „Wszystko dla przyszłości i nic do ukrycia”. Gretkowska w następujący sposób relacjonuje intencje, jakie przyświecały Piotrowi Pietrusze, pomysłodawcy plakatu:

Piękne i odważne, autentyczne. Nie w garniturach, nikogo nie udajecie. Jesteście nagie i bezbronne, bezbronne wobec prawa, pieprzonej mentalności i dumne. Wasza siła jest w determinacji, nie macie nic do stracenia ${ }^{47}$.

Za takim wyborem plakatu przemawiały jednak także inne argumenty. Partia Kobiet od samego początku zmagała się z kłopotami finansowymi, bo Gretkowska mylnie założyła, że dotację uda się pozyskać od sponsorów - przede wszystkim od kobiet, które osiągnęły sukces w biznesie. Składki, którymi obciążono szeregowe członkinie, były niewielkie, żeby nie zniechęcać gorzej sytuowanych kobiet do działalności politycznej. Z tych powodów w czasie kampanii Partia Kobiet nie miała pieniędzy na wykupienie choćby jednej reklamy bilbordowej. „To była desperacja”48 - przyznała później liderka Partii Kobiet, komentując plakat z nagimi działaczkami. Podkreślała, że ich nagość nie ma konotacji erotycznych, a w ich spojrzeniach widać determinację. Mówiła też, że kobiety po raz pierwszy rozebrały się we własnej sprawie ${ }^{49}$.

Plakat Partii Kobiet nigdy nie pojawił się na ulicach miast - funkcjonował tylko w Internecie ${ }^{50}$. Mimo to mówiły o nim polskie i zagraniczne media, szeroko komentowano go także w sieci - pod tym względem cel Gretkowskiej został osiągnięty. Jednak sam pomysł wzbudził konsternację właściwie u wszystkich grup odbiorców. Był oczywiście dość łatwym obiektem żartów:

47 M. Gretkowska, Obywatelka, op. cit., s. 78.

48 Po zmierzchu, TVP, 5 V 2011, https://vod.tvp.pl/video/po-zmierzchu,05052011,31700153 [dostęp: 11 VIII 2020].

49 Ibidem.

50 Por. A. Jakubowska, op. cit. 
Nasze przypuszczenia dotyczące oszustwa wyborczego potwierdziły się podczas jednego z programów w TV, gdzie liderka PK wystąpiła - zamiast w stroju organizacyjnym - w pełni odziana. Z kolei na stronie internetowej partii widnieje apel jednej z działaczek o chodzenie w koszulkach partyjnych. A więc nawet nie topless ${ }^{51}$ !

Inni pozowali na obiektywnych i zdystansowanych krytyków - politolog Jacek Kucharczyk poproszony o komentarz przez Luizę Łuniewską, dziennikarkę „Newsweeka” stwierdził na przykład, że to plakat dla wielkomiejskiego, intelektualnego elektoratu, którego nie doceni konserwatywna wieśs ${ }^{52}$. Jeszcze inni, jak Tomasz Karolak, który spotkał się z Gretkowską w jednym z programów telewizyjnych, reagowali niesmakiem i pogardą:

Tomasz Karolak: Z tego plakatu wynika jednoznacznie chęć zwrócenia uwagi, ale on jest absolutnie przeszarżowany.

Manuela Gretkowska: W stronę czego?

Tomasz Karolak: W stronę takiego taniego PR-u.

Manuela Gretkowska: Co to jest tani PR, jeżeli kobiety...

Tomasz Karolak: Tani PR to jest to, że najłatwiejszą i najprostszą drogą robimy coś, co może okazać się skandalizujące ${ }^{53}$.

Plakat z nagimi działaczkami różnie oceniały także feministki. Agnieszka Graff, która - jak twierdziła - przyglądała się Partii Kobiet z „ostrożną życzliwością", pomysłem na kampanię była zdumiona ${ }^{54}$ :

Rozumiem desperację - w tej kampanii media ignorują nie tylko partię Gretkowskiej, ale w ogóle kobiety i ich interesy. Jednak wkraczać do męskiego klubu nago? Z powagą ogłaszać własną „czystość”? Coś mi się zdaje, że Partia Kobiet na naszych oczach popełniła polityczne samobójstwo ${ }^{55}$.

Graff uważała, że plakat potwierdził stereotyp, iż ,kobieta w sferze publicznej to kobieta «publiczna»" "56. Publicystka zapewniała jednak, że wciąż trzyma kciuki za Partię Kobiet. Do innego kręgu wyobrażeń sięgnęła natomiast Agata Jakubowska w artykule Plakat, którego nie widziałam na ulicy. Przywołała prawdziwą historię powstania kalendarza z nagimi mieszkankami Yorkshire, z którego dochód został przeznaczony na pomoc chorym ${ }^{57}$. Kalendarz stworzony przez Angielki cieszył

51 A. Paulukiewicz, S. Klawe, Ueorgan Ludu, „Wprost” 2007 nr 39, https://www.wprost.pl/tygodnik/114438/Ueorgan-Ludu.html [dostęp: 11 VIII 2020].

52 Por. L. Łuniewska, op. cit.

53 Po zmierzchu, op. cit.

54 A. Graff, Rykoszetem. Rzecz o ptci, seksualności i narodzie, Warszawa 2008, s. 207.

55 Ibidem, s. 208.

56 Ibidem.

57 Por. A. Jakubowska, op. cit. 
się tak dużym uznaniem, że w 2003 opowiedziano o nim w filmie fabularnym Dziewczyny z kalendarza. Jakubowska pokazuje, że odmienne wartościowanie (podobnych zresztą w koncepcie plastycznym) kalendarza i plakatu może wynikać z różnych celów ich powstania. Kobiety rozbierające się, aby pomóc chorym, wypełniają tradycyjnie przypisywane im role troskliwych opiekunek - zasługują więc na docenienie. Uznanie nie należy się jednak tym, które rozbierają się, żeby przejąć władzę.

Plakat podzielił także same członkinie partii. Agnieszka Graff cytuje w swoim tekście wpis (jak można się domyślać nie jedyny) z nieaktywnego dziś forum Partii Kobiet, w którym komentująca zarzuca kierownictwu, że kontrowersyjna reklama zepchnie działania ruchu na peryferia polityki ${ }^{58}$. Problem w tym, że w momencie publikacji plakatu, partia już od dawna znajdowała się na peryferiach polityki, podjęto więc przynajmniej próbę zwrócenia uwagi na jej istnienie. Desperacja, którą przywołuje Gretkowska, jest jednak problematyczna z innych powodów. Po pierwsze, o ile można uznać argumenty pisarki, że kobiety na plakacie patrzą z godnością i powagą, trudno nie zauważyć, że ich ciała są szczupłe, młode, gładkie i jędrne. Występujące na plakacie działaczki twierdziły, że to baner zasłonił wszystkie niedoskonałości - pozostaje jednak faktem, że prawdziwe ciała zostały w ten sposób przekształcone w estetyczne obiekty. Tymczasem można sobie wyobrazić inną formę reprezentacji nagości, która nie skazywałaby kobiet na uprzedmiotowienie. Po drugie, opisując w Obywatelce historię powstawania plakatu, Gretkowska nieświadomie zdradziła, że wobec jednej z działaczek użyto przemocy (czytelnik nie poznaje jej nazwiska). Według relacji pisarki jedna z kobiet już po tym, jak zdjęcie zostało zrobione, skontaktowała się z koleżankami, które uznały, że plakat będzie kompromitujący. Pod ich wpływem zaczęła się obawiać, że za udział w kampanii partii zapłaci kłopotami w pracy. Zadzwoniła więc do Gretkowskiej z prośbą o usunięcie jej wizerunku. Liderka Partii Kobiet uznała jednak, że jest na to za późno, argumentując, że zdjęcie jest już po edycji, a ze względu na bliski termin konferencji prasowej nie można go powtórzyć. Następnego dnia kobieta wciąż nalegała na usunięcie jej z fotografii, a po jej stronie stanęła część działaczek. Gretkowska po raz kolejny odmówiła. W Obywatelce tę sytuację relacjonuje następująco:

W zwolnionym tempie widzę metaliczne łzy, precyzyjnie kalibrowane w oczach Działaczki. Nie jest zapłakaną ofiarą despotycznej wariatki (ty nic nie ryzykujesz, jesteś skandalistką), ona mną manipuluje. Za jej prośbami jest chłód, wyspekulowany kodeks postępowania z nieprzewidywalną artystką. Sekunda a dałabym się złamać, poświęciłabym zaangażowanie setek kobiet dla jednego widzimisię ${ }^{59}$.

58 Por. A. Graff, op. cit., s. 209.

59 M. Gretkowska, Obywatelka, op. cit., s. 288. 
Gretkowska nie zdradza, jakie intencje miałyby kierować działaczką i po co miałaby stosować techniki manipulacyjne. Stwierdzenie, że wycofanie plakatu albo opóźnienie jego publikacji oznaczałaby poświęcenie zaangażowania setek kobiet także wydaje się przesadzone. Trzeba wziąć pod uwagę, że działaczka zgodziła się na udział w kampanii bez wynagrodzenia, wątpliwe też, żeby z twórcami zdjęcia wiązała ją jakaś umowa. Miała zatem prawo wycofać się w każdej chwili z dowolnego powodu, a jej decyzja powinna być respektowana. Partia Kobiet miała przecież walczyć o szacunek dla kobiecych decyzji. Pisarka informuje jednak, że ostatecznie działaczka zgodziła się zostać na plakacie - nie wiemy, czy zrobiła to z własnej woli, czy dlatego że nie miała innego wyboru. W chwili publikacji plakatu ta historia nie była szerzej znana. Członkini Partii Kobiet Monika Kamieńska, która także pozowała do zdjęcia, w rozmowie z Izabellą Adamczewską przyznała natomiast:

Wzięcie udziału w sesji było dla nas wszystkich ogromnym ryzykiem. Na tym zdjęciu są też pracownica Politechniki Warszawskiej, prawniczka i maturzystka. Liczyłam się z tym, że mogę zaprzepaścić swoją karierę zawodową. Na szczęście od nikogo nie usłyszałam złego słowa ${ }^{60}$.

Warto może dodać, że po publikacji plakatu przedstawiającego nagie działaczki sondaże wskazywały wzrost poparcia dla Partii Kobiet do czterech procent.

6.

W przypadku Partii Kobiet istnieje wyraźny rozdźwięk między opisywaną dotąd sferą działań a produkowanym przez nią dyskursem ideowym. Jeśli za cytowaną na początku Nancy Fraser przyjmiemy, że interpretacja potrzeby jest aktem i interwencją, a nie reprezentacją, na poziomie żenującego performansu inicjatywa Gretkowskiej odnosiła początkowo sukcesy. Wprowadziła stan niepokoju i destabilizacji do dotąd bardzo stabilnego, męskiego systemu politycznego (co odzwierciedlają przytoczone komentarze medialne), otwierała przestrzeń, która mogła zostać na różne sposoby zagospodarowana przez kobiety, a przede wszystkim aktywizowała bierne do tej pory politycznie odbiorczynie. W przypadku Partii Kobiet sukcesem byłoby przecież nie tylko wejście do parlamentu czy zdobycie dotacji na dalszą działalność, ale także stworzenie mocnej organizacji zdolnej przetrwać przegrane wybory. Dawałaby ona szansę na przynajmniej częściowe upartyjnienie ruchu kobiecego, a w dalszej perspektywie stwarzałaby możliwość zbudowania siły politycznego nacisku na poziomie władzy ustawodawczej. Kiedy jednak z fantazmatycznego projektu partia

60 Kobiety szykuja się do polityki. Z Moniką Kamieńską rozmawiała Izabella Adamczewska, „Gazeta Wyborcza Łódź” [online 20 IX 2007], https://classic.wyborcza.pl/archiwumGW/4961471/KOBIETY-SZYKUJA-SIE-DO-POLITYKI [dostęp: 20 VIII 2020]. 
przekształciła się w realny byt, Gretkowska zaczęła wprowadzać elementy zupełnie odmiennego dyskursu. Subwersywna energia żenującego performansu była odtąd stale torpedowana przez konserwatywne deklaracje mieszczące się w porządku tradycyjnego performansu partyjnego. Im dłużej trwała kampania wyborcza, tym słabszy stawał się żenujący performans (plakat z nagimi działaczkami był właściwie jego ostatnim rozbłyskiem).

Różne sondaże przedwyborcze szacowały poparcie dla Partii Kobiet między jednym a czterema procentami głosów. Szanse na przekroczenie pięcioprocentowego progu wyborczego od początku były więc nikłe. Na niekorzyść inicjatywy Gretkowskiej zadziałał też kryzys gabinetowy, który 7 września 2007 doprowadził do samorozwiązania parlamentu. Data przedterminowych wyborów wyznaczona została na 21 października. Aby wystartować w wyborach, komitety wyborcze muszą zarejestrować listy kandydatów do Sejmu i Senatu, mając pisemne poparcie co najmniej pięciu tysięcy dorosłych obywateli stale zamieszkujących dany okręg wyborczy. Jeśli uda się zdobyć podpisy w co najmniej połowie okręgów wyborczych, komitet wyborczy może rejestrować listy kandydatów bez dalszego zbierania podpisów. Dużym partiom nie sprawia kłopotu udokumentowanie poparcia nawet $\mathrm{w}$ czasie mocno ograniczonym za sprawą przedterminowych wyborów. Ale nowa, mała i niedoświadczona Partia Kobiet już na tym etapie poniosła porażkę. Jej działaczkom nie udało się zebrać wymaganych podpisów w połowie okręgów wyborczych, zarejestrowane więc zostały tylko niektóre listy, a głosowanie na partię nie było możliwe w całym kraju. To przesądziło o wyniku jeszcze słabszym, niż się spodziewano.

Trudno jednoznacznie ocenić, dlaczego Gretkowska zrezygnowała z żenujących strategii. Prawdopodobnie uznała, że uruchomienie tradycyjnego performansu partyjnego zwiększy szanse na sukces w wyborach. Na horyzoncie pojawiła się wizja zawarcia umowy koalicyjnej z Platformą Obywatelską, która ostatecznie nie doszła do skutku, ale najwyraźniej dała liderce Partii Kobiet złudzenie, że może być traktowana poważnie przez doświadczonych politycznych graczy. Gretkowska przyjęła wówczas jedną z najważniejszych strategii tradycyjnego performansu politycznego polegającą na zawieraniu kompromisów i takim wyrażaniu poglądów, żeby pozyskać jak największą grupę wyborców. Niestety, kwestia prawa do przerywania ciąży, która doprowadziła do powstania Partii Kobiet, była najbardziej konfliktogenną z perspektywy ówczesnego układu sił politycznych. Dlatego właśnie od zmiany poglądów na temat aborcji Gretkowska zaczęła rozwijanie dyskursu konserwatywnego. „Nie zdecydowałabym się na aborcję. To są moje poglądy wynikające ze światopoglądu religijnego"

61 Polko, nie wstydź się! Z Manuela Gretkowska rozmawiają Mira Suchodolska i Dariusz Wilczak, „Newsweek” 2007 nr 1, https://www.newsweek.pl/polko-nie-wstydz-sie/ym7m2x7 [dostęp: 20 VIII 2020]. 
- powiedziała w grudniu 2006 (a więc tuż przed oficjalną rejestracją partii) dziennikarzom „Newsweeka”. Wtedy jeszcze broniła prawa innych do wyboru. Jednak miesiąc później twierdziła już, że „uważa aborcję za czyn straszny”"62, a potem dodawała: „O aborcję rozbiły się wszystkie ruchy kobiece, dlatego nie chcę o tym rozmawiać, bo wtedy na drugi plan przechodzą ważniejsze postulaty" "63. W Obywatelce twierdzi, że chciała, by na zjeździe członkiń podjęto wspólną decyzję, czy Partia Kobiet będzie walczyć o legalizację aborcji. Pisze jednak również, że w czasie spotkań organizowanych przez partię w różnych miastach kobiety domagały się jasnej deklaracji w tej sprawie:

Mamy rozmawiać o programie, strukturach. Daję się wciągnąć w godzinną sprzeczkę z jedną osobą. Aborcja!!!

- Natychmiast ogłosić nasze poparcie! - żąda.

Odsyłam ją do Borówek, oni mają (bez ironii) bardzo dobry program równościowy i aborcja jest jednym z najważniejszych postulatów. U nas nie będzie do zjazdu. Dopiero się tworzymy, nie chcę rozbicia partii przed powstaniem struktur. Czy dołączając ten postulat, spowodujemy natychmiastową zmianę przepisów? Nie. Czy damy się sprowadzić do jednej kwestii w dyżurnych dyskusjach medialnych? Tak. [...] Pomyślmy choć raz politycznie, jednocząc się i nie wystawiając na odstrzał ${ }^{64}$.

Dla Gretkowskiej polityczne myślenie oznaczało zatem, przynajmniej czasowe, milczenie kobiecej partii o najważniejszej dla kobiet kwestii. Zarówno przed, jak i po okresie działalności w Partii Kobiet, autorka manifestu Dość upokorzeń bardzo ostro żądała liberalizacji ustawy regulującej prawo do przerywania ciąży (w 2016 nazwała „kompromis” aborcyjny niewolnictwem ${ }^{65}$ ). Można zatem przypuszczać, że w 2007 nie tyle zmieniła poglądy, ile uznała, że więcej zyska, zachowując je dla siebie i podkreślając swoją - motywowaną religijnie - negatywną ocenę aborcji.

Szybko okazało się, że nie tylko aborcja jest w Partii Kobiet tematem tabu. Chociaż energia żenującego perfromansu domagałaby się głoszenia wyrazistych politycznych poglądów, na przekór niej Gretkowska podkreślała: organizacja nie jest ani lewicowa, ani prawicowa. Powtarzała, że wejdzie w alianse z każdym, kto zadba o interesy kobiet, i tego typu stwierdzenia musiały niepokoić. Czy bowiem pisarka była gotowa sprzymierzyć się na przykład z prawicowymi ekstremistami, gdyby ci zdecydowali się spełnić któryś z jej postulatów? To pytanie tym bardziej zasadne, że wraz z rozwojem działalności politycznej Gretkowska coraz częściej

62 E. Jarzębowska, Kobiety podzieliła aborcja, „Gazeta Wyborcza Olsztyn” [online 12 I 2007], https://classic.wyborcza.pl/archiwumGW/4800380/Kobiety-podzielila-aborcja [dostęp: 11 VIII 2020 ].

63 Ibidem.

64 M. Gretkowska, Obywatelka, op. cit., s. 260.

65 Por. Zarażeni wirusem pogardy. Z Manuela Gretkowska rozmawia Renata Kim, „Newsweek” $2016 \mathrm{nr} 44$. 
sprowadzała walkę o prawa kobiet do zabiegania o poprawę sytuacji matek i dzieci. Jak ognia wystrzegała się też mówienia o feminizmie, a w Obywatelce kilkakrotnie przeciwstawia siebie „radykalnym feministkom” i opisuje swoje z nimi konfrontacje $^{66}$. Inne działaczki partii również często podkreślały, że nie są feministkami. Najsilniej konserwatywne poglądy Gretkowskiej wybrzmiały jednak w Krakowie na spotkaniu organizowanym przez feministyczne pismo „Zadra”, podczas którego odmówiła wpisania postulatów społeczności LGBTQ+ do programu Partii Kobiet. Pytana potem o to kilkakrotnie, odpowiadała niezmiennie:

Ta sprawa dotyczy niewielkiego procentu osób. A cała reszta postulatów dotyczy także lesbijek. Weźmy sprawę alimentów. Która kobieta, z lewa czy z prawa, powie, że to jest problem ideologiczny? Żadna kobieta nie przejdzie obojętnie obok dziecka, które jest głodne ${ }^{67}$.

Gretkowska uznawała zatem, że prawo homoseksualnych, biseksualnych i transseksualnych kobiet do godnego życia nie tylko nie jest warte uwagi, ale wręcz jest sprawą ,ideologiczną”. Trudno też nie zauważyć, że sprawa alimentów dotyczy tylko tych lesbijek, które mają za sobą heteroseksualne małżeństwa. W Polsce nie istnieje przecież możliwość zawarcia homoseksualnego małżeństwa, nie ma więc także rozwodów czy oficjalnego dzielenia opieki nad dzieckiem. Założenie, że wszystkie kobiety troszczą się o dobro dzieci, wpisuje się natomiast w konserwatywne wyobrażenia o kobiecości i jej powinnościach. Retorykę tę oczywiście dostrzegły i krytykowały feministki - choćby Magdalena Środa ${ }^{68}$ (od początku sprzyjająca partii) czy Beata Kozak ${ }^{69}$. To pogłębiło tylko rozdział między partią a środowiskiem feministycznym.

Ostatecznie Partia Kobiet stała się więc partią środka, która reprezentować może tylko kobiety spełniające tradycyjną definicję kobiecości, matki zatroskane o dobro swoich dzieci. W początkowym okresie działalności żenujący kobiecy performans był siłą napędową partii i potencjalnie oferował najbardziej obiecujące rezultaty. Ponieważ jednak był wygaszany i konsekwentnie zastępowany dyskursem konserwatywnym, nigdy nie dowiemy się, jaka byłaby jego rzeczywista polityczna sprawczość, gdyby postulaty ideowe partii zostały do niego dostrojone.

66 Por. M. Gretkowska, Obywatelka, op. cit.

67 Politycy przehandlowali kobiety. Z Manuela Gretkowska rozmawiała Miłada Jędrysik, „Gazeta Wyborcza" [online 17 XII 2006], https://classic.wyborcza.pl/archiwumGW/4779411/POLITYCY-PRZEHANDLOWALI-KOBIETY [dostęp: 11 VIII 2020].

68 Por. M. Środa, Kobiety $i$ wtadza, Warszawa 2009.

69 Por. B. Kozak, Kobiecizm, op. cit. 